\title{
Interactive comment on "Tectonic Exhumation of the Central Alps Recorded by Detrital Zircon in the Molasse Basin, Switzerland" by Owen A. Anfinson et al.
}

\section{Anonymous Referee \#3}

Received and published: 3 July 2020

General reviewer comments: In their paper, Anfinson and co-authors apply detrital zircons geochronology coupled with trace and rare elements analysis to link sediment provenance in the foreland with mechanisms of exhumation and denudation of the Central Alps. Zircons geochronology and trace element analysis are performed on high temporal resolution ( $\sim 1$ Myrs) on Eocene-Miocene strata collected in the Swiss Northern Alpine Molasse basin. Chemical analysis is used to precisely differentiate continental crust derived zircons from the magmatic arc- derived zircons. The results are used to i. interpreting mechanism and timing of exhumation of the Central Alps north of the Periadriatic line, ii. the hydrographic evolution of the drainage divides and, iii. deriving first-order interpretation for decreasing sedimentation rates, recorded 
by a transgression to a marine environment in the Oligocene-Miocene strata, during the exhumation of the Lepontine metamorphic units. They apply a Multidimensional Scaling (MDS) (Vermeesch et al., 2015) statistical approach (Figure 10) where they compare U-Pb significant cluster of ages to guide the reader into the visual detection of provenance contributions to the foreland. In Figure 10, they improve the MDS plots (Vermeesch et al., 2015) with automated generated pie-charts of age populations per sample. This visually show a major shift which is recorded during the deposition of Lower Freshwater Molasse (LFM) at 22 Ma (Lucerne section) towards a major Penninic unit derived age component. This major provenance transition is used as a core observation for further speculation on temporal-spatial evolution of the architecture of the alpine orogeny in this sector of the Alps. Varisican information (except for a single data point) forms the major age component in the Miocene strata and are interpreted to represent the inset of Lepontine dome (Penninic units) exposure at surface. Using this provenance shift, the author coupled the tectonic exhumation of the Lepontine dome with a significant decrease of the sediment supply in the adjacent foreland. An invoked mechanism to decrease denudation rates is associated with the slip along the Simplon fault, subsequent lower relief, and exposure of high-grade lithologies with lower erodibility. These interpretations which differ from previous studies are well augmented but, however, the author avoid to address some important outstanding questions which arise while reading throughout the text: Why different thermochronometers record this major exhumation phase of the Lepontine dome in the Molasse and the U$\mathrm{Pb}$ zircons analysis lack this information? What are the implications of using a unique geo/thermochronometers for interpretation of hinterlands evolution over time with respect of multi-proxy thermochronology approach? What is the lag-time between the onset of the Lepontine exhumation and the record of erosion in the Molasse? How spatially distributed differences in erosion rates might have biased the observed age distributions? These questions need to be developed a little further in the discussion. Overall, their approach and the analytical procedure is well explained and, although not novel for the study area (e.g. von Eynatten and Wijbrans, 2003; Spiegel et al., 
2004), they use a nice set of figures coupled with a well logically written text to guide the reader into their argumentation and casualties' relationship. The background information is detailed, however, a significant part of the current debate which focuses on how the record of erosion detected from multi-thermochronometers analysis and associated biases is transferred into the foreland sedimentary sequences is missing. Provenance analysis cannot be de-coupled from source information, a compilation of available in-situ ages would improve for example the tectonic map of Figure 1. This, in my opinion, could be pushed a bit further in the discussion and could be used as an additional key for interpreting the evolution of the Central Alps as recorded by its sedimentary foreland.

\section{SpeciïňĄc comments:}

53-54. Provenance from foreland strata can be used to unravel long-term exhumation from the hinterland, however this need to be coupled with source information. There has been some recent effort in doing so which would need to be acknowledged (e.g. Mineral Fertility: Malusa et al., 2016- modern river analysis correlated with source information e.g. Gemignani et al. 2017). Did the author think about providing averaged in-situ age constraints for the exposed Lepontine unit? These would help them to characterize source provenance in the foreland. 355. What is the grain size of the analysed Zr? This need to be specified. There is any relationship between age distribution vs analysed grain's size fraction? 403. please correct with superscript 504-505. It would be useful to add a sentence describing how binned age distributions described in section 4 were computed. In particular, you could briefly describe how the age cluster proportions were calculated. 505. flowing? 570. Please double-check groups percentage. 576-579. Please check age groups proportion and correct percentages, if needed. 679-681. More recent modern river data has been discussed and need to be accounted for the discussion of significant age peaks north of the Periadriatic line. 682. Interesting observation but needs a substantial comparison with information collected south of the Periadriatic line.

Printer-friendly version

Discussion paper
Interactive

comment

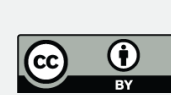


Interactive comment on Solid Earth Discuss., https://doi.org/10.5194/se-2020-44, 2020.

SED

Interactive

comment 